\title{
Adsorption and Desorption of Au Nanoparticles Monitored by Infrared Spectroscopy
}

\author{
Tadaaki Nagao Non-member (NIMS \& ICOR-JST, NAGAO.Tadaaki@nims.go.jp) \\ Dominik Enders Non-member (ICORP-JST, Dominik.Enders@nims.go.jp) \\ Tomonobu Nakayama Member (NIMS \& ICORP-JST, NKAYAMA.Tomonobu@nims.go.jp) \\ Masakazu Aono Non-member (NIMS \& ICORP-JST, AONO.Masakazu@nims.go.jp)
}

Keywords : nanoparticles, infrared absorption spectroscopy, in situ monitoring

We show that infrared absorption spectroscopy can probe the adsorption and desorption process of Au nanoparticles onto silica surface from colloidal suspension. When the $\mathrm{Au}$ nanoparticles come into the evanescent field of the infrared (IR) beam in attenuated total reflection (ATR) geometry, strong vibrational signal is detected due to the surface enhanced IR absorption. Quantitative analysis of the adsorption kinetics is possible by monitoring the time dependence of the IR signals.

Figure 1 shows the in situ ATR-IR spectra in the range of $v(\mathrm{OD})$ and $v(\mathrm{CH})$ during the adsorption of the AuNP on the APTES treated $\mathrm{SiO} 2 / \mathrm{Si}$ surface. As can be seen from this figure, the relative absorption signals of $v(\mathrm{OD})$ and $v(\mathrm{CH})$ increase after the surface is exposed to AuNP suspension. This is in agreement with the fact, that the origin of this behaviour is increasing surface enhanced IR absorption (SEIRA) due to an increasing surface density of AuNP. For $t \geq 30$ min the changes become very small indicating the saturation of the particle adsorption.

The time dependence of the absorption intensity of these

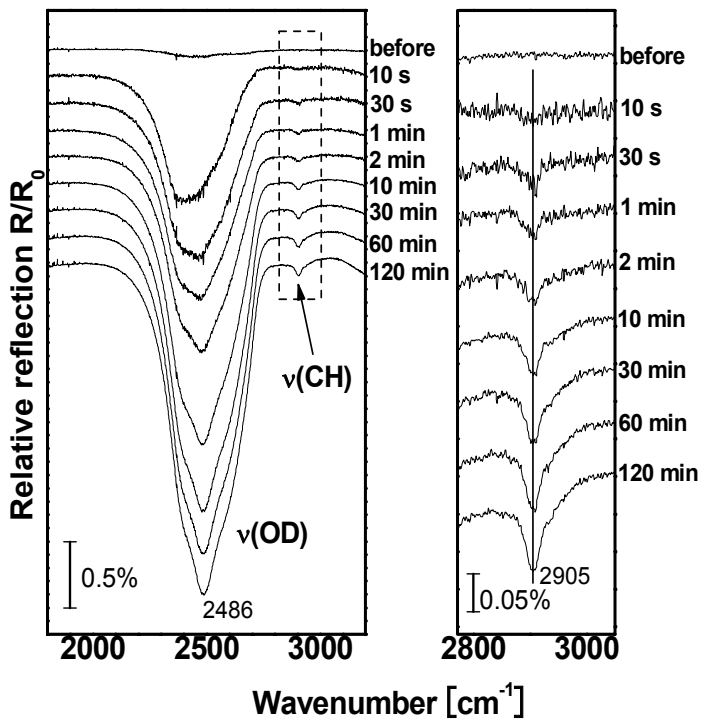

Fig. 1. IR absorption signal during the Au nanoparticle adsorption process onto $\mathrm{SiO}_{2} / \mathrm{Si}$ substrate. Graph in the right side is the magnification of the dotted rectangle in the left graph. The reference spectrum $R_{0}$ was obtained with fresh $\mathrm{D}_{2} \mathrm{O}$ contacting the $\mathrm{SiO}_{2} / \mathrm{Si}$ surface. The spectra are vertically shifted against each other vibrational peaks can be seen better, when the absorption intensity is plotted versus time, as shown in Fig. 2 with (ם) v(OD) and ( $\bigcirc)$ $v(\mathrm{CH})$. That the time dependence in the two absorption intensities being equal each other points to the fact that both, the OD and the $\mathrm{CH}$ stretch signal become SEIRA enhanced in correlation with the coverage, as the AuNP adsorption takes place. Therefore these signals are assigned to the vibrations of the $\mathrm{D}_{2} \mathrm{O}$ and citrate molecules surrounding the $\mathrm{Au}$ nanoparticles. Gray cure is the theoretical fit to the experiments by using the theory of diffusion-limited first order Langumuir kinetics. The agreement is excellent and we can conclude that the strong afffinity of $\mathrm{Au}$ nanoparticles to the substrate and electrostatic coulomb repulsion between the particles play important roles in this adsorption kinetcs. That is, Au nanoparticles are firmly immobilized on the APTES layer, and the following incoming nanoparticles are repelled out from the already adsorbed sites. This leads to the formation of uniform submonolayaer film as observed in our scanning electron micrograph (shown in the inset of Fig. 2).
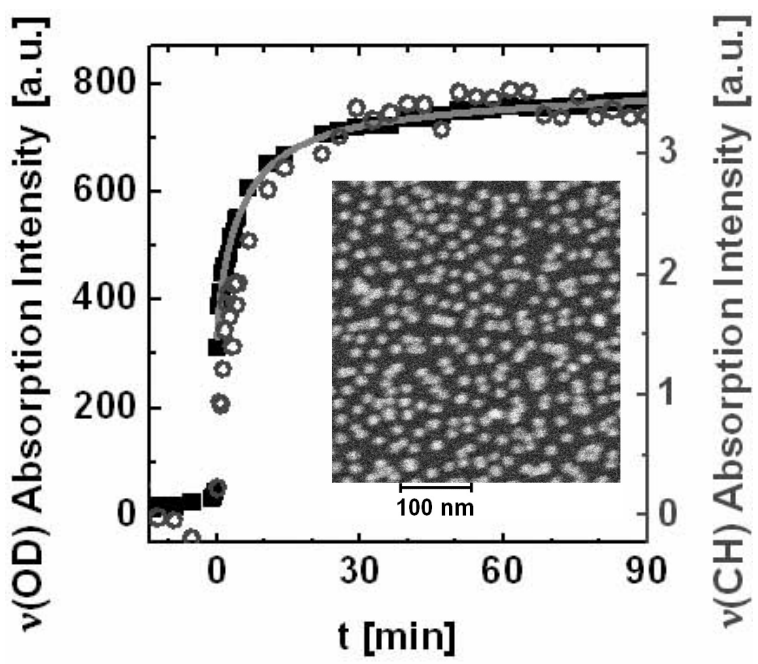

Fig. 2. Time evolution of IR absorption signals (integrated intensities) of $\mathrm{OD}$ (filled square) and $\mathrm{CH}$ (open circles) vibrational modes during the $\mathrm{Au}$ nanoparticle adsorption process onto silica surface. Gray curve is the best fit result using equation (1). Inset is the scanning electron micrograph (10kV beam energy) of the $\mathrm{Au}$ nanoparticle film taken after the saturation of $\mathrm{Au}$ adsorption 


\title{
赤外分光による $\mathrm{Au}$ ナノ粒子の吸着脱離過程のモニタリング
}

\author{
非会員 長尾 忠昭 $* * *$ 非会員 Dominik Enders** \\ 正 員 中山 知信 $* * *$ 非会員 青野 正和 $* * *$
}

\author{
Adsorption and Desorption of Au Nanoparticles Monitored by Infrared Spectroscopy \\ Tadaaki Nagao *,**, Non-member, Dominik Enders**, Non-member, Tomonobu Nakayama*,**, Member, \\ Masakazu Aono*,**, Non-member
}

We show that infrared absorption spectroscopy can probe the adsorption and desorption process of Au nanoparticles onto silica surface from colloidal suspension. When the Au nanoparticles come into the evanescent field of the infrared (IR) beam in attenuated total reflection (ATR) geometry, IR vibrational signal is detected due to the surface enhanced IR absorption. Quantitative analysis of the adsorption kinetics is possible by monitoring the time dependence of the IR signals.

キーワード : ナノ粒子, 赤外吸収, その場モニタリング

Keywords : nanoparticles, infrared absorption spectroscopy, in situ monitoring

\section{1. まえがき}

表面増強ラマン散乱や表面プラズモン誘電センサーなど のセンサー材料として真空蒸着法による金ナノ粒子膜が良 く使用されている。一方，コロイドを原料とした金ナノ粒 子膜も, 簡便さ・化学的安定性・膜モフォロジーの制御と いう点で優れるため多くの研究がなされ, 応用が進みつつ ある ${ }^{(1) \sim(3)}$ 。ラマン散乱や赤外吸収などの表面増強センサー においては，増強度の最適化のために金属膜のモフォロジ 一の制御が重要である。しかし，膜のモフォロジーの実時 間モニタリングについてはこれまで殆ど研究が報告されて いない。最近我々は, シリコン-コロイド溶液界面における $\mathrm{Au}$ ナノ粒子膜の成長の実時間モニタリングが, 赤外吸収分 光法によって可能であることを明らかにし，溶液中金属膜 の成長制御のひとつの手法として研究を始めた ${ }^{(4)}(5)$ 。本稿 では,この試みについて, 最近の実験結果を紹介したい。

\section{2. 赤外吸収分光法による Au 微粒子のモニター}

$\langle 2 \cdot 1\rangle$ 表面増強赤外吸収(SEIRA) Au ナノ粒子の周 りには電場が集中し, その効果により粒子近傍の分子振動 の吸収シグナルが数十から数百倍にも増強される場合があ

\footnotetext{
* 物質・材料研究機構 ナノシステム機能センター 干305-0044 つくば市並木 1-1

Nano System Functionality Center

National Institute for Materials Science (NIMS)

1-1 Namiki, Tsukuba 305-0044

* 科学技術振興機構 ICORP

干332-0012 埼玉県川口市本町 4-1-8

ICORP, JST

4-1-8 Honcho, Kawaguchi, Saitama 332-0012
}

る。この効果は表面増強赤外吸収 (surface enhanced infrared absorption: SEIRA）と呼ばれ, 表面から 2-3 分子層程度の分 子からの振動シグナルが特に強く検出されるとされてい $ろ^{(6) \sim(8)}$ 。ここでは, この効果を用い, $\mathrm{Au}$ 粒子の吸着ダイナ ミクスのモニターを試みた。図 1 に $\mathrm{Au}$ 吸着の模式図を示す。 下地表面はアミノ基で終端された（アミノプロピルトリエ トキシランで表面処理）自然酸化膜で覆われたシリコン結 晶を用いた。 $\mathrm{Au}$ ナノ粒子（平均直径 $11 \mathrm{~nm}$ ) はクエン酸還 元法で作成した。我々の実験では溶媒として水の代わりに 重水を用いたが, これにより IR 吸収スペクトルにおいて水 を用いる場合に生じる O-H 伸縮振動ピークと C-H ピークの

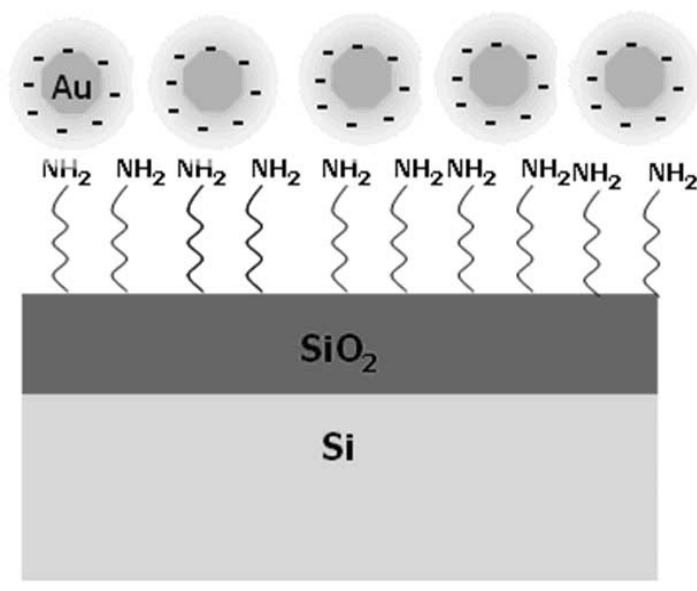

Fig. 1. Au nanoparticles are adsorbed onto amino treated $\mathrm{SiO}_{2} / \mathrm{Si}$ substrate. 
オーバーラップを防げるため，各ピークの定量的な解析が 容易となる。なお， IR 光は図の下側から（Si 側から）全反 射(attenuated total reflection: ATR)の条件で入射し，界面から 溶液中へとエバネッセント波が染み出す。このエバネッセ ント波をプローブとして, 界面に吸着した $\mathrm{Au}$ ナノ粒子の周 囲の重水やクエン酸分子の分子振動（OD 或いは $\mathrm{CH}$ 振動） を検出する。

〈2·2〉 $\mathrm{Au}$ ナノ粒子の吸着 図 2 は $\mathrm{Au}$ ナノ粒子吸着 過程における IR スペクトルである。 $2486 \mathrm{~cm}^{-1}$ にブロード で大きな吸収が現れるが，これは，Au粒子への電場集中に よる SEIRA 効果により表面増強された重水の OD 伸縮シグ ナルである。界面層, 中間層, バルクの吸収シグナルの成 分が重なっている。 $2400 \mathrm{~cm}^{-1}$ 付近にある界面の成分が，コ ロイド溶液導入直後に減少しているため, 界面の水の状態 が変わっていることが示唆される。また， $2905 \mathrm{~cm}^{-1}$ の微弱 な吸収は，下地表面処理剂のアミノプロピルトリエトキシ ラン，あるいは，作製時に $\mathrm{Au}$ 粒子の周りに吸着したクエン 酸分子のどちらかに由来する $\mathrm{CH}$ 伸縮振動シグナルである。 $\mathrm{OD}, \mathrm{CH}$ 両シグナルは，Au コロイド溶液をシリカ表面に暴 露した直後から強度が増し，数十分後には飽和する。

図 3 に OD 及び CH 伸縮振動強度を時間に対してプロット

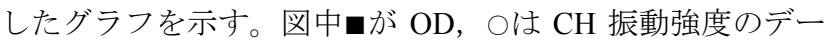
タ点である。 $\mathrm{CH}$ 振動は双極子強度が小さく, OD 振動に比 ベて吸収強度は二桁小さい。しかし，図 3 を見ると CH 振動 の強度は OD 振動と完全に同期しており, 同じキネティクス に従うことが一目瞭然である。OD 伸縮振動シグナルは $\mathrm{Au}$ 粒子由来であることが明らかであるので，ここで検出した $\mathrm{CH}$ 伸縮振動も下地表面処理剤からのものではなく, $\mathrm{Au}$ 粒

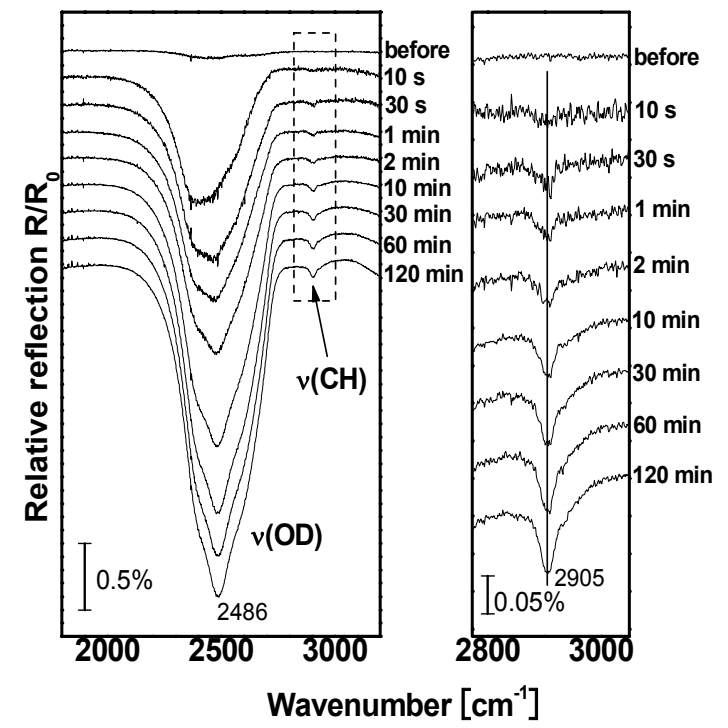

Fig. 2. IR absorption signal during the Au nanoparticle adsorption process onto $\mathrm{SiO}_{2} / \mathrm{Si}$ substrate. Graph in the right side is the magnification of the dotted rectangle in the left graph. The reference spectrum $R_{0}$ was obtained with fresh $\mathrm{D}_{2} \mathrm{O}$ contacting the $\mathrm{SiO}_{2} / \mathrm{Si}$ surface. The spectra are vertically shifted against each other.
子に付随するシグナルであることが分かる。つまりここで 観測した $\mathrm{CH}$ 振動は $\mathrm{Au}$ 粒子を覆うクエン酸による $\mathrm{CH}$ 振動 であると同定できる。

これらの振動強度の時間依存性から, Au ナノ粒子の吸着 キネティクスを議論することができる。図 3 の挿入図は $\mathrm{Au}$ ナノ粒子膜の走査電子顕微鏡(SEM)像である。この写真から わかるようにクエン酸の負電荷によるクーロン反発（図 1 参照）により概ね $\mathrm{Au}$ 粒子間の平均距離は十分離れており, 増強効果は個々の粒子周りの電場集中効果が主であるとみ なしても良い（粒子閒の双極子場の効果も若干寄与する）。 また, IR 光のビーム径は直径 $1 \mathrm{~mm}$ 程度であり, 測定した IR 吸収強度はマクロな平均情報であり, そのため $\mathrm{Au}$ 粒子の吸 着密度に比例しているものと考えてよい。

$\mathrm{Au}$ 粒子はマイナスに帯電し, 下地とは配位結合あるいは 静電力により比較的強く結合する。その結果, 吸着した $\mathrm{Au}$ 粒子は下地上に固定化される。また, SEM 観察により, Au 粒子は均一に吸着しているため吸着エネルギーは下地表面 全域にわたって均一であると思われる。さらに，一層目の 吸着が完結すると, あとは粒子同士の反発のため, SEM で 観察されたように 2 層以上は吸着しない。この様な場合の 吸着の最も単純化されたモデルとしては Langmuir 吸着のモ デルがあるが，実際にその様な単純な吸着キネティクスに 従うものかどうかが興味深い。そこで, Langmuir 吸着モデ ルに従う場合の被覆率の時間依存性の式,

$$
\theta(t)=1-e^{-c k_{L^{2}}}
$$

を用いて, 図 3 の実験データをフィットしてみた。ここで, $\theta$ は吸着子の被覆率, $c$ は溶液中の吸着粒子（通常は分子）

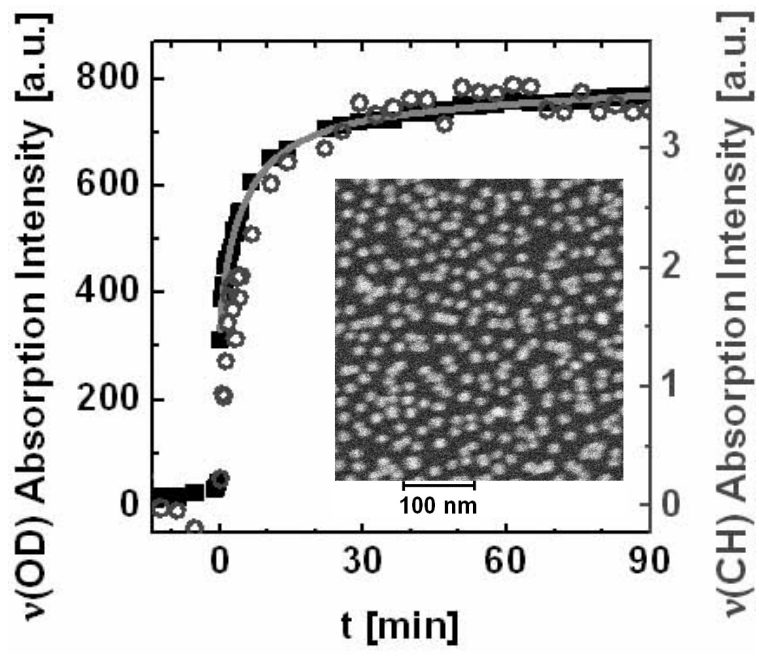

Fig. 3. Time evolution of IR absorption signals (integrated intensities) of $\mathrm{OD}$ (filled square) and $\mathrm{CH}$ (open circles) vibrational modes during the $\mathrm{Au}$ nanoparticle adsorption process onto silica surface. Gray curve is the best fit result using equation (1). Inset is the scanning electron micrograph ( $10 \mathrm{kV}$ beam energy) of the Au nanoparticle film taken after the saturation of $\mathrm{Au}$ adsorption. 
Henry

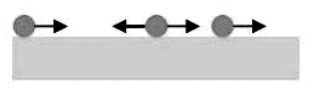

BET

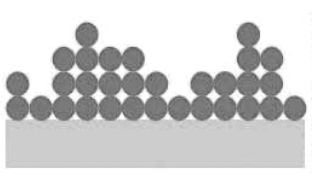

Freundlich
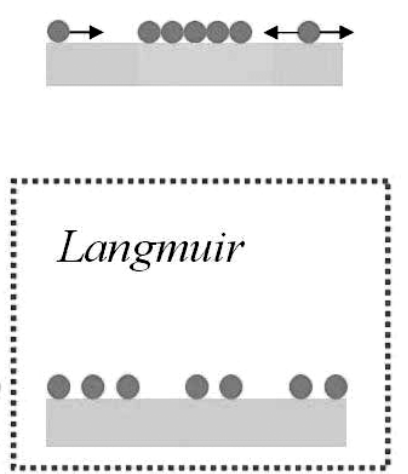

Fig. 4. Illustrations of the adsorption models of Henry, (mobile adsorbates) Freundlich (mobile adsorbates, inhomogeneous adsorption), BET (Brunauer, Emmett, and Teller: multilayer growth), and Langmuir (immobile, homogeneous, submonolayer).

の濃度, $k_{L}$ は吸着レート, $t$ は時間である。指数 $\alpha$ の值が 1 の場合は通常 (ガス吸着などの場合)の Langumuir キネティ クスであり， $\alpha=1 / 2$ の場合は拡散に律速された拡張 Langmuir モデルの場合に相当することが知られている。図 3 の灰色のカーブがベストフィットの結果であるが, 実験 と計算の結果は驚くほど一致している。実験は数回行い, その結果に対して得たフィッティングパラメータの值は, $c k_{L}=0.134 ， \alpha=0.39-0.42$ となった。ここで得られた $\alpha$ の值 は拡張 Langmuir モデルに非常に近い值である。つまり $\mathrm{Au}$ 粒子が表面まで届くレートは, 溶液中の $\mathrm{Au}$ 粒子のブラウン 運動で律速される。一度界面に到着し吸着した $\mathrm{Au}$ 粒子は固 定化されて，同じ場所への粒子の吸着をブロックすること を示している。これは, 先に述べたように $\mathrm{Au}$ ナノ粒子がマ イナスに帯電した粒子であり，粒子同士は斥力で反発しあ うことを考えると, 良く理解できる。ここで扱う吸着粒子 は, 通常の原子や分子ではなく, 重い金属原子数万個から なり, クエン酸分子で覆われ帯電した巨大な複合体である。 また，吸着サイトも特定サイトがあるわけではなく SEM 像 からわかるように全くランダムに吸着している。しかし， にも関らず，分子などに比べて一見複雑に見える大きな粒 子の場合にも, 単純な Langumuir モデルによりそのキネティ クスをクリアに説明できることは大変興味深い。

〈2·3〉 Auナノ粒子の脱離 引き続き, 下地に固定化 された $\mathrm{Au}$ ナノ粒子を脱離させる実験を行った。 $\mathrm{Au}$ に対し て強く結合するチオール分子を用いて, $\mathrm{Au}$ ナノ粒子とクエ ン酸分子，あるいは $\mathrm{Au}$ ナノ粒子と下地アミノ基との結合を 切断することで $\mathrm{Au}$ 粒子を脱離させることが出来る。図 4 は アミノエタンチオール(AET: HS $-\mathrm{C}_{2} \mathrm{H}_{4}-\mathrm{NH}_{2}$ ) 溶液に飽和吸着 した $\mathrm{Au}$ ナノ粒子膜を暴露した際の IR スペクトルの変化を 示したものである。暴露するアミノエタンチオールは少し ずつ濃度を変化させた。 $\mathrm{OD}$ 及び $\mathrm{CH}$ 振動の吸収強度が図 2 とは異なり, 上向きに変化している。これは, 図 2 の場合 (a)

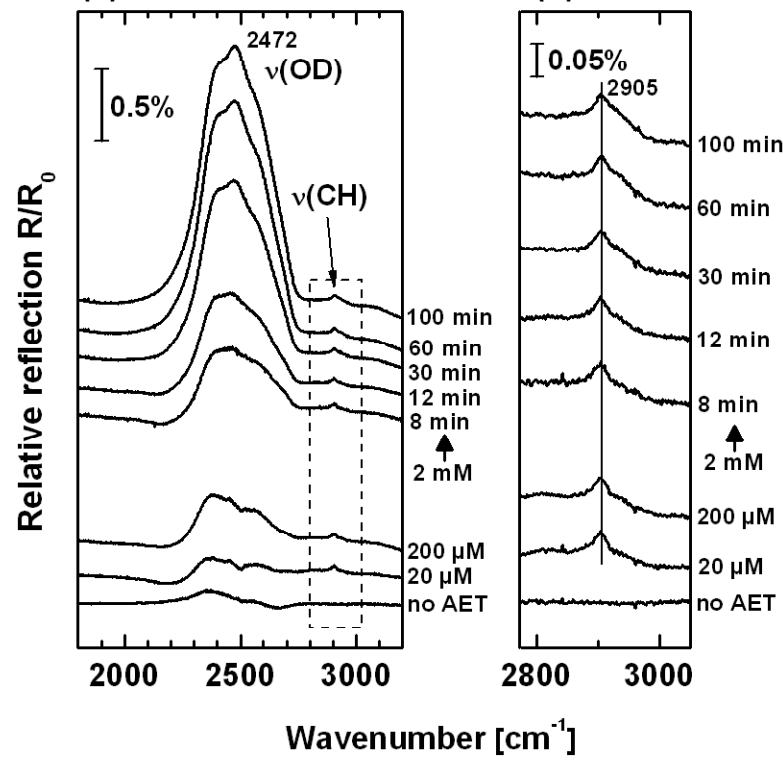

Fig. 5. IR adsorption signal during adsorption process of the $\mathrm{Au}$ nanoparticles on the $\mathrm{SiO}_{2} / \mathrm{Si}$ surface: Graph in the right side is the magnification of the dotted rectangle in the left graph. The reference spectrum $R_{0}$ was obtained with $\mathrm{D}_{2} \mathrm{O}$ in the flow cell contacting the $\mathrm{SiO}_{2} / \mathrm{Si}$ surface.

とは反対に表面の $\mathrm{Au}$ ナノ粒子数が減少していることに対 応する。OD 振動はアミノエタンチオール濃度が $2 \mathrm{mM}$ 以上 にならないと顕著な変化が生じないが, $\mathrm{CH}$ 振動は僅か 20 $\mu \mathrm{M}$ の低濃度で急峻に変化し, その後はあまり変化しない。 このことは, 予想通りアミノエタンチオールが $\mathrm{Au}$ 表面のク エン酸を速やかに置換することを示し, その後, $\mathrm{Au}$ 表面に 配位結合あるいは静電力で結合した下地のアミノ基に変わ ってアミノエタンチオールが吸着し, $\mathrm{Au}$ 粒子の脱離が徐々 に生じることを示している。

$\mathrm{OD}$ 及び $\mathrm{CH}$ 強度の変化が飽和したあとに SEM 観察を行 った結果， $\mathrm{Au}$ ナノ粒子は実際に表面に殆ど存在しないこと が確認できた。Auナノ粒子を脱離させた表面を再び重水洗 浄したのちに $\mathrm{Au}$ コロイドに暴露すると, $\langle 2 \cdot 2\rangle$ 節の過程が 再び観測される。その後の脱離も同様であり, 吸着-脱離の プロセスが何度でも繰り返し可能であることが分かった。

\section{3. むすび}

本記事では，赤外光を用いてモニターした固液界面にお ける $\mathrm{Au}$ ナノ粒子の吸着脱離ダイナミクスについての研究 を紹介した。SEIRA は表面増強ラマン散乱に続いて, 簡便 なケミカルセンシングの新技術として注目されているが, ナノ粒子表面の化学的環境変化や粒子自身の吸着キネティ クスの実時間情報を得ることも可能であることが分かっ た。材料科学においてコロイドや細胞を用いた結晶成長や 生体膜の形成など, 固液界面での微粒子のダイナミクスが 重要になる局面は多い。本研究のような結果を蓄積し, 今 後微粒子の吸着, 膜形成のダイナミクスの理解が進むこと 
で，液中での無機・生体ナノ材料の探索・開発研究が進む ことを期待している。

(平成 19 年 5 月 7 日受付, 平成 19 年 7 月 17 日再受付)

\section{文献}

(1) G. Frens : "Controlled nucleation for the regulation of the particle size in monodisperse gold solutions", Nat. Phys. Sci., Vol.241, pp.20-22 (1973)

(2) O. P. Repnytska, et al. : "Structural organisation of nucleic acids from tumour cells", Faraday Discuss., Vol.126, pp.61-76 (2004)

(3) T. Sato, D. Brown, and F. G. Johnson : "Nucleation and growth of nano-gold colloidal lattices", Chem. Comm., p.1007 (1997)

(4) D. Enders, T. Nagao, A. Pucci, and T. Nakayama : "Reversible adsorption of $\mathrm{Au}$ nanoparticles on $\mathrm{SiO}_{2} / \mathrm{Si}$ : an in situ ATR-IR study", Surf. Sci., Vol.600, pp.L71-75 (2006)

( 5 ) D. Enders, T. Nagao, T. Nakayama, and M. Aono : "In Situ Surface Enhanced Infrared Absorption Spectroscopy for the Analysis of the Adsorption and Desorption Process of $\mathrm{Au}$ Nanoparticles on the $\mathrm{SiO}_{2} / \mathrm{Si}$ Surface", Langmuir, in press.

(6) A. Hartstein, J. R. Kirtley, and J. C. Tang : "Enhancement of the Infrared Absorption from Molecular Monolayers with Thin Metal Overlayers", Physical Review Letters, Vol.45, pp.201-204 (1980)

( 7 ) M. Osawa : "Dynamic Process in Electrochemical Reactions Studied by Surface Enhanced Infrared Absorption Spectroscopy (SEIRAS)", Chem. Soc. Jpn., Vol.70, pp.2861-2880 (1997)

(8) M. Futamata: "Adsorbed State of 4,4'-BiPy and $\mathrm{BiPyH}_{2}{ }^{2+}$ on $\mathrm{Au}$ (111) Electrode”, J. Phys. Chem., Vol.105, pp.6933-6942 (2001)

長 尾 忠 昭

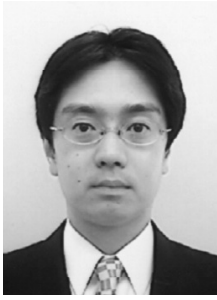

（非会員） 1966 年 9 月 23 日生。1994 年 9 月早 稲田大学大学院理工学研究課博士後期課程中 退。理学博士 (1995 年早稲田大学)，1994 年東 京大学理学部, 2001 年東北大学金属材料研究所 を経て, 2004 年から物質・材料研究機構 主幹 研究員。専門は, 表面物理学, ナノサイエンス, 材料科学。現在低次元金属ナノ構造の電子物 性，光物性（赤外応答など）の研究に従事。

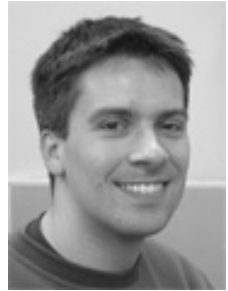

（非会員） 1975 年 6 月 11 日生。 2005 年 12 月 ハイデルベルグ大学 (ドイツ) 大学院博士課程 卒業。2006 年自然科学博士 (ハイデルベルグ大 学)。現在科学技術振興機構 (JST-ICORP) 研究 員。専門は, 表面物理学, ナノサイエンス, 分 光物理学。現在固液界面での金属ナノ粒子や金 属ナノ薄膜の表面増強赤外吸収分光の研究に 従事。

中 山 知 信

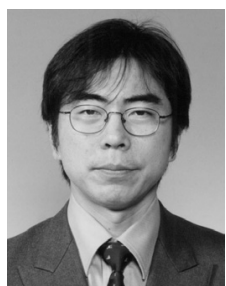

（正員） 1962 年 2 月 12 日生。1988 年 3 月 東 京工業大学大学院総合理工学研究科材料科学 専攻修士課程修了。理学博士（1999 年東京大 学)。三井金属 (株), 理化学研究所を経て, 現 在物質・材料研究機構ナノシステム 機能セン ター・ナノ機能集積グループリーダー（筑波大 学助教授併任)。走査プローブ顕微鏡ベースの 新規ナノ計測技術開発，ナノマテリアル研究， ナノバイオ研究に従事。

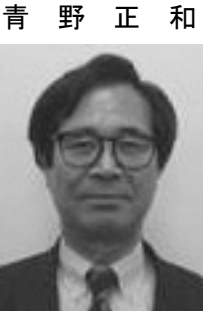

（非会員） 1944 年 4 月 20 日生。1972 年 3 月東 京大学大学院工学研究課 博士課程修了（工学 博士), 1972 年無機材質研究所, 1886 年理化学 研究所 (1996 年大阪大学教授兼務) を経て, 2002 年から物質・材料研究機構 ナノマテリアル研 究所長, 2006 年から物質・材料研究機構 ナノ テクノロジー基盤領域長およびナノシステム 機能センター長。米国真空学会, 英国物理学会, 物質材料研究機構フェロー。 